\title{
Effect of Trichoderma spp. on Growth Promotion and Antioxidative Activity of Pepper Seedlings
}

\author{
Sonja Tančić-Živanov ${ }^{1}$ \\ https://orcid.org/0000-0001-9556-2732 \\ Slađana Medić-Pap ${ }^{1}$ \\ https://orcid.org/0000-0002-1426-1143 \\ Dario Danojević ${ }^{1}$ \\ https://orcid.org/0000-0002-4048-8413 \\ Dejan Prvulović ${ }^{2}$ \\ https://orcid.org/0000-0002-1880-4934
}

${ }^{1}$ Institute of Field and Vegetable Crops, Novi Sad, Serbia, 'University of Novi Sad, Faculty of Agriculture, Novi Sad, Serbia.

Received: 2018.11.15; Accepted: 2020.04.02.

*Correspondence: sladjana.medicpap@ifvcns.ns.ac.rs; Tel.: +381-21-4898357 (S.M.P.)

\section{HIGHLIGHTS}

- Two different Trichoderma strain-dependent modes of actions.

- Perspective Trichoderma isolates induce formation and accumulation of ROS.

- Positive correlation between PPx, SOD, CAT activity and germination.

- Nine Trichoderma isolates significantly increase root weight of pepper. seedlings

\begin{abstract}
One of the main challenges in pepper production is to enhance seed germination energy and germination, and to grow healthy nursery plants with strong root system. Trichoderma species colonize roots as they grow and provide season-long benefits to plants, which is why Trichoderma species are widely used as plant growth promoter agents and promoters of plant defence mechanisms. This study evaluated the effectiveness of seed biopriming with Trichoderma isolates for growth promotion of pepper plants in early stage and their effects on seedling physiology. Nine out of ten Trichoderma isolates positively affected root weight of pepper seedlings, while three out of ten positively affected shoot weight. Root and shoot lengths were mainly unaffected. Germination energy was positively affected by five isolates with up to $40 \%$ increase compared to the control, while germination was significantly enhanced by two isolates with up to $22 \%$ increase. Considering seedling physiology, two different strain-dependent modes of actions were expressed. Promising Trichoderma isolates induced formation and accumulation of reactive oxygen species (ROS) which acted as signal molecules that increased germination energy and germination. Positive correlation was found between pyrogallol peroxidase, superoxide dismutase, catalase activity and germination in plants treated with these isolates.
\end{abstract}

Keywords: biopriming; germination; growth enhancement; seeds; ROS. 


\section{INTRODUCTION}

Pepper (Capsicum spp.) is one of the world's major vegetable and spice crops. The most cultivated species is Capsicum annuum L., originating from Central America. The total cultivation area under pepper in the world was almost 2 million hectares in 2018 [1]. The main challenge in pepper production, besides dealing with diseases, is to enhance germination energy and seed germination, and to grow healthy nursery plants with strong root system. Seed deterioration is also an important issue in crop production and can cause seed to be discarded [2]. Therefore, the increase of germination and restoration of seed quality is often required. Seed priming has successfully demonstrated to improve seed germination and seedling establishment for many field crops, such as wheat, sugar beet, maize, soybean, and sunflower [3].

Living organisms are constantly exposed to biotic and abiotic stress and are forced to efficiently balance growth, reproduction and defence under adverse conditions. Plants contain numerous enzymatic (superoxide dismutase, peroxidase and catalase) and non-enzymatic (glutathione, ascorbic acid, atocopherol, and phenolic compounds) mechanisms, which prevent oxidative damage by scavenging free radicals before they attack membranes or other seed components [4]. During the germination process, strong increase in the respiratory activity and enhanced production of reactive oxygen species (ROS) was recorded [5]. Reactive oxygen species are usually considered as toxic molecules in seed physiology, but nowadays there is evidence that ROS also function as signalling molecules that activate in a wide range of defence responses to various stimuli [5]. Therefore, cellular levels of ROS have to be tightly controlled at both production and consumption levels [6]. Cellular antioxidant machinery, involving detoxifying enzymes and antioxidant compounds, eliminate potentially toxic ROS produced under stressful conditions or control ROS concentrations due to regulation of various signalling pathways. Non-toxic levels of ROS must be maintained in order to utilize them as signalling molecules. Evolutionally, it is assumed that - when cells once learn to deal with ROS toxicity, they are able to utilize ROS as signalling molecules [7].

Considering the growing demand for organic food production, the use of biofertilizers and biopesticides is an alternative for sustaining high eco-friendly production. The fact that Trichoderma species are resistant to the most chemical pesticides, classifies those species as good biocontrol and integrated control agents $[8,9]$. The main biocontrol mechanisms of Trichoderma species are mycoparasitism, antibiosis and competition for soil nutrients and space [10]. Those mechanisms make Trichoderma strongly aggressive to a broad range of phytopathogenic fungi [11], but besides biocontrol, Trichoderma species have been known as plant growth promoter agents and promoters of plant defence mechanisms [8,12]. Trichoderma harzianum fully colonizes roots as they grow and provides at least season-long benefits to plants [13]. A series of morphological and biochemical changes, initiated by Trichoderma spp. colonization and penetration of plant root tissues, are considered to be a part of the plant defence response [14]. Specific strains of Trichoderma spp. can stimulate defence responses in its host plants and are known as one of the best induced systemic resistance (ISR) agents [12]. Additionally, Trichoderma spp. root colonization also frequently enhances root growth and development, crop productivity, resistance to abiotic stress and nutrients uptake and utilization [14]. It is important to underline that within a single Trichoderma species, not all isolates are capable of promoting plant growth. For that reason, plant - Trichoderma sp. interaction depends on the plant species and the genotype used as well [15]. So far, it has been reported that $\mathrm{T}$. harzianum, T. viride and T. pseudokoningi improve growth of sweet and/or hot pepper, but the physiology of plant - Trichoderma interaction remains unclear $[16,17]$. Therefore, the aim of this study was to test the ability of Trichoderma strains to promote growth of pepper plants in early stage and their effects on the seedling physiology.

\section{MATERIAL AND METHODS}

\section{Isolation of biocontrol agents}

Trichoderma spp. isolates were obtained from soil samples originating from various soil types and localities in Serbia, mainly from the Vojvodina Province in 2012. Selective water agar (WA) media amended with streptomycin was used to isolate Trichoderma from soil samples by particle-plating method. A total of 20 soil particles (of weight $0.0001 \mathrm{~g}$ per particle) per sample were analyzed seven days after incubation at room temperature. The emerging fungal colonies were observed under microscope, and transferred on Potato Dextrose Agar (PDA) and Synthetic low-Nutrient Agar (SNA) media for further analyses of 
morphological characters. All Trichoderma isolates were refined to single-spore isolates for further research and preserved at $+4 \stackrel{\circ}{\circ}$.

\section{Preparation of conidia suspension}

A conidia suspension of ten tested Trichoderma isolates was prepared from seven days old culture of the Trichoderma isolate flooded with $10 \mathrm{~mL}$ of sterilized distilled water and scraped by sterile glass rod. Such suspensions were filtered through cheesecloth, and conidial concentrations were adjusted to $10^{6}$ conidia per $\mathrm{mL}$ by Neubauer's haemocytometer.

\section{Plant material and seed treatment with Trichoderma spp.}

Trichoderma spp. growth promoting activity was tested on 'California Wonder' sweet pepper seeds at Laboratories of Institute of Field and Vegetable Crops, Novi Sad during 2014. Pepper seeds were sterilized in $1 \%$ sodium hypochlorite solution for $5 \mathrm{~min}$ and rinsed in sterile distilled water. Sterilized seeds were treated with each Trichoderma isolate suspensions separately, according to the modified Mukhtar and coauthors [18] method. Seeds were dipped in seed-coating suspensions for 30 min and air dried on filter paper for $24 \mathrm{~h}$ at room temperature. Seeds treated with sterile distilled water were used as a control.

\section{Growth promoting activity test}

One hundred of sweet pepper seeds treated with Trichoderma suspensions were germinated in four replicates by Blotter method in a growth chamber with $12 \mathrm{~h}$ photoperiod at $25 \pm 1^{\circ} \mathrm{C}$ [19]. Germination energy (GE) and germination (G) were calculated on day seven and day 14, respectively, as a percentage of germinated seeds. Shoot and root maximal length, and weight of all pepper seedlings were measured on day 14. Vigour Index (V.I.) was calculated according to Asaduzzaman and coauthors [16]. Immediately after length and weight measurements, root and shoot samples were frozen at $-80{ }^{\circ} \mathrm{C}$ for further enzyme analyses.

\section{Enzyme extraction}

Biochemical analyses were performed at the Laboratory for Biochemistry, University of Novi Sad Faculty of Agriculture, during 2014. Frozen shoots and roots (2 g each) were homogenized in $10 \mathrm{~mL}$ of phosphate buffer $(0.1 \mathrm{M}, \mathrm{pH} 7.0)$. Homogenates were centrifuged for 20 min at $10.000 \times \mathrm{g}$ and filtered. The supernatants were used to test enzyme activity and to determine intensity of lipid peroxidation.

\section{Membrane lipid peroxidation and protein content}

Lipid peroxidation (LP) was measured at $532 \mathrm{~nm}$ using the thiobarbituric acid test (TBA) test [20]. The enzyme extract $(0.5 \mathrm{~mL})$ was incubated with $2 \mathrm{~mL}$ of $20 \%$ trichloroacetic acid (TCA) containing $0.5 \%$ thiobarbituric acid for $40 \mathrm{~min}$ at $95^{\circ} \mathrm{C}$. The reaction was stopped by cooling on ice bath for 10 min and the product was centrifuged at $10.000 \times \mathrm{g}$ for $15 \mathrm{~min}$. The total amount of TBA-reactive substances is given as $\mathrm{nmol}$ malondialdehyde equivalents (MDAE) $\mathrm{mg}$ protein ${ }^{-1}$. Protein content in homogenates was determined using bovine serum albumin as a protein standard [21]. The Bradford assay is based on the direct binding of Coomassie brilliant blue G-250 dye (CBBG) to proteins at arginine, tryptophan, tyrosine, histidine, and phenylalanine residues.

\section{Assay of catalase activity}

Catalase (CAT) (EC 1.11.1.6) activity was determined according to Sathya and Bjorn [22]. The decomposition of $\mathrm{H} 2 \mathrm{O} 2$ was followed as a decrease in absorbance at $240 \mathrm{~nm}$. The enzyme extract $(0.02$ $\mathrm{mL}$ ) was added $(0.02 \mathrm{~mL}$ extract of shoots or $0.05 \mathrm{~mL}$ extract of roots, separately) was added to the assay mixture containing $1 \mathrm{~mL}$ of $50 \mathrm{mM}$ potassium phosphate buffer $\left(\mathrm{pH} \mathrm{7.0)}\right.$ and $10 \mathrm{mM} \mathrm{H}_{2} \mathrm{O}_{2}$. The activity of the enzyme was expressed as IU per $1 \mathrm{mg}$ of protein (IU mg-1 protein).

\section{Assay of superoxide dismutase activity}

Superoxide dismutase (SOD) (EC 1.15.1.1) activity was assayed according to the method of Mandal and coauthors [20] slightly modified by measuring its ability to inhibit photochemical reduction of nitro blue tetrazolium (NBT) chloride. The reaction mixture contained $50 \mathrm{mM}$ potassium phosphate buffer ( $\mathrm{pH} 7.8$ ), 75 $\mu \mathrm{M}$ NBT, $0.1 \mathrm{mM}$ EDTA, $13 \mu \mathrm{M}$ L-metionine, $2 \mu \mathrm{M}$ riboflavin and $0.015 \mathrm{~mL}$ of the enzyme extract. It was kept under a fluorescent lamp for $20 \mathrm{~min}$, and then the absorbance was read at $560 \mathrm{~nm}$. One unit of the 
SOD activity was defined as the amount of enzymes required to inhibit reduction of NBT by $50 \%$. The activity of the enzyme was expressed as IU mg-1 protein.

\section{Assay of peroxidase activity}

Peroxidase (EC 1.11.1.7) activity was measured using guaiacol (guaiacol peroxidase; GPx) and pyrogallol (pyrogallol peroxidase; PPx) as substrates [23]. Peroxidase activity (GPx and PPx) was expressed as IU mg-1 protein. Pyrogallol peroxidase activity: includes the measurement of the content of purpurogallin - a product of pyrogallol oxidation. The enzyme extract $(0.02 \mathrm{~mL})$ was added to the assay mixture containing $3 \mathrm{~mL}$ of $180 \mathrm{mM}$ pyrogallol and $0.02 \mathrm{~mL}$ of $2 \mathrm{mM} \mathrm{H}_{2} \mathrm{O}_{2}$. The absorbance was recorded at $430 \mathrm{~nm}$ during 5 minutes. Guaiacol peroxidase activity consists of the assay of tetraguaiacol - a coloured product of guaiacol oxidation in the investigated sample. The enzyme extract $(0.03 \mathrm{~mL})$ was added to the assay mixture containing $3 \mathrm{~mL}$ of $20 \mu \mathrm{M}$ guaiacol and $0.02 \mathrm{~mL}$ of $3 \mathrm{mM} \mathrm{H}_{2} \mathrm{O}_{2}$. The absorbance was recorded at $436 \mathrm{~nm}$ during 5 minutes.

\section{Glutathione peroxidase (GSH-Px) activity}

Glutathione peroxidase (GSH-Px) activity was assessed in the brain spectrophotometrically [24]. Applying this technique, GSH formation was assayed by measuring the conversion of nicotinamide adenine dinucleotide phosphate (NADPH) to NADP. The oxidation of NADPH was measured spectrometrically at $340 \mathrm{~nm}$. The assay mixture contained $0.05 \mathrm{M}$ phosphate buffer at a pH of 7.0, $5 \mathrm{mM}$ EDTA, $2 \mathrm{mM} \mathrm{NaN3}, 1$ $\mathrm{mM} \mathrm{GSH}, 0.2 \mathrm{mM} \mathrm{NADPH}$, and $4 \mu \mathrm{g}$ of GSH reductase. The sample $(0.02 \mathrm{~mL})$ was added to $2.88 \mathrm{~mL}$ of the assay mixture. The reaction was initiated by the addition of $0.1 \mathrm{~mL}$ of $2.5 \mathrm{mM} \mathrm{H} 2 \mathrm{O} 2$. A blank assay with buffer instead of a sample was used to correct for any non-enzymatic oxidation of GSH and NADPH by peroxide.

\section{Reduced glutathione}

Reduced glutathione (GSH) was determined using Ellman reagent [25] and expressed as mg GSH mg1 protein. In this method, $0.5 \mathrm{~g}$ of plants tissues were homogenized in $5 \mathrm{~mL} 20 \%$ TCA solution. The samples were centrifuged at $10.000 \times \mathrm{g}$ for $15 \mathrm{~min} .2 .5 \mathrm{~mL}$ of $0.1 \mathrm{M}$ potassium phosphate buffer $(\mathrm{pH} 7.5)$ with $1 \mathrm{mM}$ EDTA and $0.5 \mathrm{~mL}$ of $3 \mathrm{mM} \mathrm{5,5}$ '-dithiobis-(2-nitrobenzoic acid) (DTNB) was added in $0.5 \mathrm{~mL}$ supernatant and after $20 \mathrm{~min}$ the absorbance was measured at $412 \mathrm{~nm}$. The glutathione concentration was determined by a standard curve prepared with GSH standard.

\section{Total antioxidant activity (TAA)}

The reduction of molybdenum $(\mathrm{VI})$ to molybdenum $(\mathrm{V})$ by the root and shoot extracts was used to assess the total antioxidant activity following the method described by Berk and coauthors [26]. The standard curve for total antioxidant was plotted using ascorbic acid solution. The standard curve was constructed using different concentrations of ascorbic acid, and the results were expressed as mg ascorbic acid equivalents (AAE) per milligram of protein (mg AAE mg-1 protein). An aliquot of $0.01 \mathrm{~mL}$ of the sample solution containing extract of peppers was combined in a glass tube with $5.0 \mathrm{~mL}$ of reagent solution $(0.6 \mathrm{M}$ sulfuric acid, $28 \mathrm{mM}$ sodium phosphate, and $4 \mathrm{mM}$ ammonium molybdate). The tubes were capped and incubated in a water bath at $95{ }^{\circ} \mathrm{C}$ for $90 \mathrm{~min}$, after the samples had cooled to ambient temperature, the absorbance of the aqueous solution was measured at $695 \mathrm{~nm}$ against a blank. A typical blank solution contained $5.0 \mathrm{~mL}$ of the reagent solution, and it was incubated under the same conditions as the rest of the samples.

\section{2,2-Azino-bis (3-ethylbenzothiazoline-6-sulfonic acid) (ABTS) radical cation scavenging activity}

The scavenging activity of the plant extracts on ABTS. ${ }^{+}$radical was measured according to the method of $\mathrm{Re}$ and coauthors [27] with some modifications. The standard curve for total antioxidant capacity (activity) was plotted using ascorbic acid solution. ABTS-+ cation radical was produced by the reaction between $7 \mathrm{mM}$ ABTS in water and $2.45 \mathrm{mM}$ potassium persulfate (1:1), stored in the dark at room temperature for $24 \mathrm{~h}$ before use. ABTS + solution was then diluted with water to obtain an absorbance of 0.900 at $734 \mathrm{~nm}$. After the addition of $0.02 \mathrm{~mL}$ of plant extract to $3.0 \mathrm{~mL}$ of diluted ABTS + solution, the absorbance was measured at 2 hours after the initial mixing. An appropriate solvent blank was run in each assay. All the measurements were carried out at least three times. 


\section{Statistical analyses}

The data were processed in Statistica 12.0 (StatSoft, Dell Inc., USA) using two-factorial analysis of variance (isolate and plant organ being the first and second factor) with Duncan's multiple test intervals at a significance level of 0.05 . Data in percentages (GE and $G$ ) were transformed by ArcSin transformation. Pearson correlation coefficients were determined separately by plant organs at the significance level of probability 0.05 and 0.01 . Average values from each isolate were transformed and used for Principal Component Analysis (PCA).

\section{RESULTS}

\section{Growth Promoting Activity}

In this study we were able to detect growth responses of pepper seedlings as early as 14 days postinoculation with Trichoderma isolates. In addition, the pathogen-free environment enabled us to study the direct influence of Trichoderma isolates on the growth response of pepper seedlings without any disease suppression.

Table 1. Duncan test of growth parameters of pepper seedlings treated with Trichoderma spp. isolates

\begin{tabular}{|c|c|c|c|c|c|c|c|}
\hline Isolate & RL (cm) & SL (cm) & RW (mg) & SW (mg) & GE (\%) & G (\%) & V.I. \\
\hline TR-1 & $\begin{array}{c}31.67^{\mathrm{cde}} \\
(5.15)\end{array}$ & $\begin{array}{c}21.34^{\mathrm{cd}} \\
(0.66)\end{array}$ & $\begin{array}{l}2.19 \mathrm{e} \\
(0.38)\end{array}$ & $\begin{array}{l}21.30^{a} \\
(0.44)\end{array}$ & $\begin{array}{c}51^{c} \\
(4.03)\end{array}$ & $\begin{array}{c}55^{\mathrm{b}} \\
(4.17)\end{array}$ & $294.96 \mathrm{bc}$ \\
\hline TR-2 & $\begin{array}{c}38.26^{a b} \\
(2.41)\end{array}$ & $\begin{array}{c}25.86^{a b c} \\
(1.46)\end{array}$ & $\begin{array}{l}3.77^{d} \\
(0.18)\end{array}$ & $\begin{array}{c}22.50^{a} \\
(0.73)\end{array}$ & $\begin{array}{c}67^{\mathrm{a}} \\
(5.38)\end{array}$ & $\begin{array}{c}70^{\mathrm{cd}} \\
(6.99)\end{array}$ & $469.07^{a}$ \\
\hline TR-3 & $\begin{array}{l}\mathbf{4 1}^{1.60^{a}} \\
(1.45)\end{array}$ & $\begin{array}{l}11.13^{\mathrm{ef}} \\
(0.08)\end{array}$ & $\begin{array}{l}6.61^{a b} \\
(0.70)\end{array}$ & $\begin{array}{l}17.92^{b} \\
(0.32)\end{array}$ & $\begin{array}{c}58^{\mathrm{ac}} \\
(1.55)\end{array}$ & $\begin{array}{c}89^{a} \\
(7.59)\end{array}$ & $473.80^{a}$ \\
\hline TR-4 & $\begin{array}{c}33.28^{b c d} \\
(0.79)\end{array}$ & $\begin{array}{l}8.64^{f} \\
(0.53)\end{array}$ & $\begin{array}{l}6.75^{a} \\
(0.58)\end{array}$ & $\begin{array}{l}12.95^{d} \\
(0.37)\end{array}$ & $\begin{array}{c}18^{b} \\
(2.07)\end{array}$ & $\begin{array}{l}79 \text { acd } \\
(0.46)\end{array}$ & $329.20^{c}$ \\
\hline TR-5 & $\begin{array}{c}27.22^{\text {defg }} \\
(1.13)\end{array}$ & $\begin{array}{c}9.68^{f} \\
(0.39)\end{array}$ & $\begin{array}{l}5.37^{b c} \\
(0.26)\end{array}$ & $\begin{array}{l}11.72^{\mathrm{e}} \\
(0.34)\end{array}$ & $\begin{array}{c}4^{d} \\
(4.31)\end{array}$ & $\begin{array}{c}68^{\mathrm{bcd}} \\
(4.86)\end{array}$ & $253.59 \mathrm{bc}$ \\
\hline TR-6 & $\begin{array}{c}23.36^{f g} \\
(3.18)\end{array}$ & $\begin{array}{c}8.46^{f} \\
(0.28)\end{array}$ & $\begin{array}{l}4.55^{\mathrm{cd}} \\
(0.28)\end{array}$ & $\begin{array}{l}10.30^{f} \\
(0.59)\end{array}$ & $\begin{array}{c}6^{d} \\
(5.99)\end{array}$ & $\begin{array}{l}70^{\mathrm{bcd}} \\
(2.18)\end{array}$ & $221.03^{b}$ \\
\hline TR-7 & $\begin{array}{c}25.74^{\text {efg }} \\
(1.09)\end{array}$ & $\begin{array}{l}8.18^{f} \\
(0.77)\end{array}$ & $\begin{array}{c}5.49^{a b c} \\
(0.11)\end{array}$ & $\begin{array}{l}11.54^{\mathrm{e}} \\
(0.34)\end{array}$ & $\begin{array}{c}4^{d} \\
(3.63)\end{array}$ & $\begin{array}{c}74^{\mathrm{bcd}} \\
(0.76)\end{array}$ & $250.93^{b c}$ \\
\hline TR-8 & $\begin{array}{c}31.19 \text { cde } \\
(0.72)\end{array}$ & $\begin{array}{c}9.45^{f} \\
(0.29)\end{array}$ & $\begin{array}{c}5^{5.82^{a b c}} \\
(0.50)\end{array}$ & $\begin{array}{l}13.20^{d} \\
(0.41)\end{array}$ & $\begin{array}{c}12^{\mathrm{bd}} \\
(3.55)\end{array}$ & $\begin{array}{l}81^{\text {acd }} \\
(2.63)\end{array}$ & $335.99^{c}$ \\
\hline TR-9 & $\begin{array}{c}28.87^{\text {cdef }} \\
(1.75)\end{array}$ & $\begin{array}{c}9.48^{f} \\
(0.13)\end{array}$ & $\begin{array}{l}4.79^{\text {cd }} \\
(0.28)\end{array}$ & $\begin{array}{c}13.73^{\mathrm{cd}} \\
(0.35)\end{array}$ & $\begin{array}{c}49^{c} \\
(3.35)\end{array}$ & $\begin{array}{c}84^{\mathrm{ac}} \\
(3.20)\end{array}$ & $328.57^{c}$ \\
\hline TR-10 & $\begin{array}{c}28.99^{\text {cdef }} \\
(3.64)\end{array}$ & $\begin{array}{c}8.89^{f} \\
(0.53)\end{array}$ & $\begin{array}{c}5.91^{\text {abc }} \\
(0.23)\end{array}$ & $\begin{array}{l}13.53^{d} \\
(0.41)\end{array}$ & $\begin{array}{c}55^{\mathrm{ac}} \\
(1.15)\end{array}$ & $\begin{array}{l}78^{\text {acd }} \\
(0.79)\end{array}$ & $294.67^{b c}$ \\
\hline $\mathrm{H}_{2} \mathrm{O}$ & $\begin{array}{c}34.47^{\mathrm{bc}} \\
(4.94)\end{array}$ & $\begin{array}{c}16.82^{\mathrm{de}} \\
(0.53)\end{array}$ & $\begin{array}{l}1.96^{e} \\
(0.33)\end{array}$ & $\begin{array}{l}14.80^{c} \\
(0.52)\end{array}$ & $\begin{array}{c}27^{b} \\
(4.02)\end{array}$ & $\begin{array}{c}67 \mathrm{bd} \\
(0.81)\end{array}$ & $339.94^{c}$ \\
\hline
\end{tabular}

*Legend: RL - Root Length; SL - Shoot Length; RW - Root Weight; SW - Shoot Weight; GE - Germination energy; G - Germination; V.I. - Vigour Index; Values with different letters in the columns differ significantly at a significance level of $p<0.05$; SE values are given in parentheses.

All Trichoderma tested isolates, with the exception of TR-1, had significant positive effects on root weight of pepper seedlings. Besides root weight, some isolates positively affected up to five out of six measured growth parameters (Table 1). Germination energy was positively influenced by five isolates, while germination was significantly enhanced by two isolates (Table 1). Considering all significant positive influences and Vigour Index, isolates TR-2 and TR-3 can be selected as the most promising. Shoot length and weight were mostly negatively affected, which can be explained by higher plants activity in roots enhancement.

\section{Seedling Physiology Analyses}

According to PCA the first five components which were explained in the analysis were higher than eigenvalue 1 . These five components explained $91.74 \%$ of the total variance, while the first component accounts for approximately $41.82 \%$ variation. Considering the impact of tested traits on the major components (Table 2), the most positive effect in the first factor was noted for GSH, ABTS and GSH-Px all in root. In the second component, the most significant effect was noted for average length (AL) and 
average weight (AW) of shoots, and germination energy. Since these traits mostly affected the first two components, these the traits also mostly affected the distribution of strains in Figure 1.

Correlations of these properties with GE, G, AW, and AL were more or less negative, which means that GSH, GSH-Px, and ABTS (all in the root) should be as low as possible. If one looks at the individual charts of these three variables (Figs $2 \mathrm{~A}, 2 \mathrm{~B}$ and $2 \mathrm{C}$ ) in root, it can be noticed that pepper seeds treated with the isolates TR-2, TR-3, TR-4, TR-9, and TR-10 had the lowest values for GSH, GSH-Px, and ABTS, and the highest germination values (Fig. 2). Therefore, the strains TR-1, TR-5, TR-6, TR-7 and control (H2O), as shown in Figure 1, were grouped above the rest of previously mentioned isolates, because they had overall higher values for these three biochemical parameters and low germination.

According to Figure 1, all tested Trichoderma isolates grouped according to their ability to enhance germination and growth parameters into three groups. Group I consists of three isolates which did not enhance the GE (TR-5, TR-6, and TR-7). Group II consists of two isolates (TR-4 and TR-8) that poorly affected GE, but final $G$ was satisfying which would classify them as isolates with lower effect. Group III consists of isolates with positive effect on both root weight and G (TR-3, TR-9, and TR-10). Isolates TR-2 and TR-1 affected high shoot length and weight with low difference between GE and G.

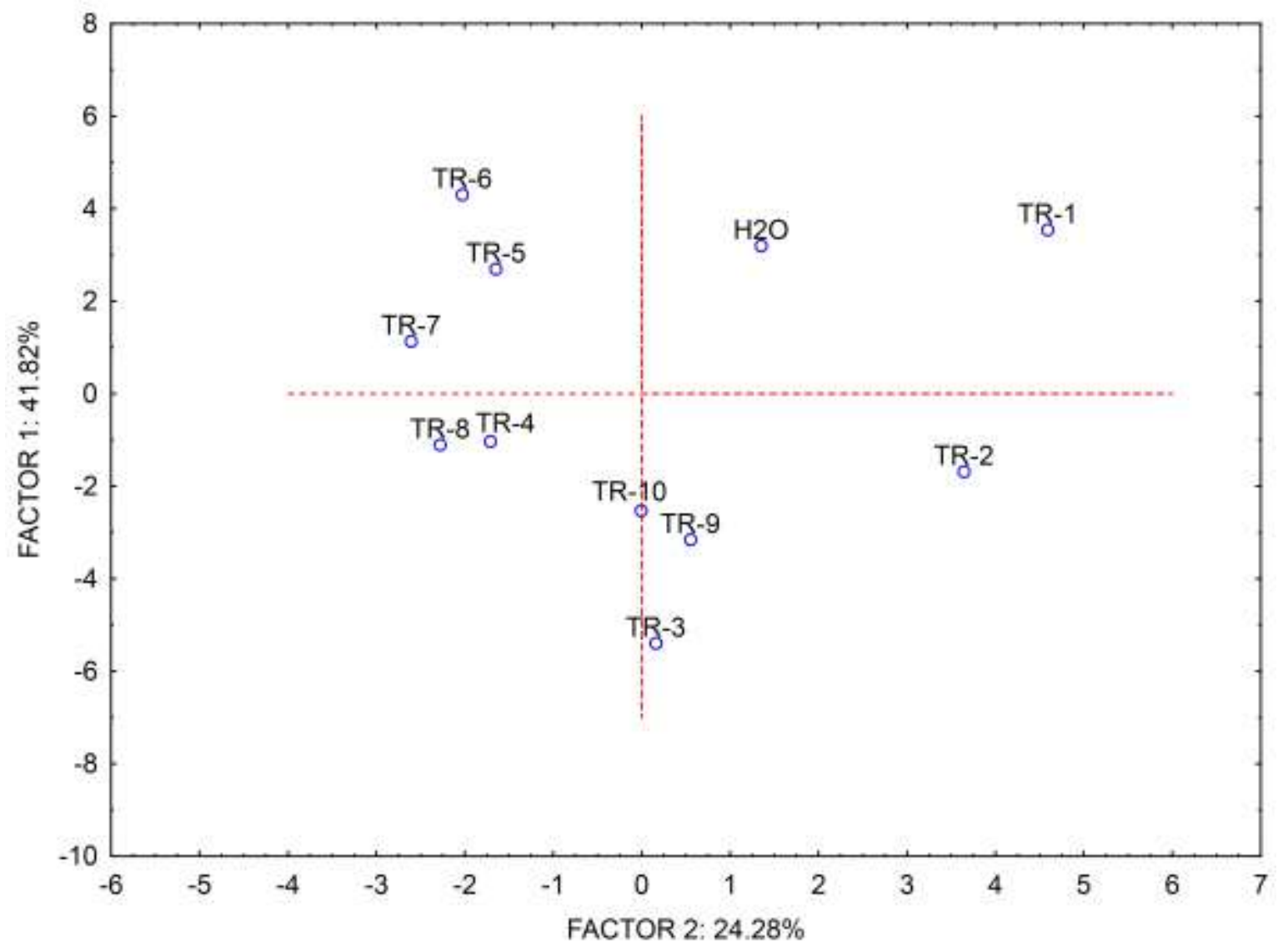

Figure 1. PCA biplot of evaluated Trichoderma isolates according to all tested parameters 
Table 2. PC scores for all analysed traits in pepper seedlings

\begin{tabular}{|c|c|c|c|c|c|}
\hline Traits & PC 1 & PC 2 & PC 3 & PC 4 & PC 5 \\
\hline \multicolumn{6}{|l|}{ Shoot } \\
\hline GSH (mg GSH mg ${ }^{-1}$ protein) & -0.288 & -0.549 & -0.272 & -0.412 & 0.153 \\
\hline TAA (mg AEE $\mathrm{mg}^{-1}$ protein) & -0.547 & -0.316 & -0.695 & -0.247 & 0.120 \\
\hline ABTS (mg AEE mg-1 protein) & -0.349 & -0.401 & -0.736 & -0.230 & 0.034 \\
\hline SOD (IU mg $\mathrm{mg}^{-1}$ protein) & -0.745 & -0.406 & -0.046 & -0.037 & -0.039 \\
\hline GPx (IU mg-1 protein) & -0.788 & 0.313 & 0.155 & -0.379 & -0.153 \\
\hline PPx (IU mg-1 protein) & -0.833 & 0.398 & 0.158 & -0.235 & -0.143 \\
\hline LP (nmol MDA mg ${ }^{-1}$ protein) & -0.624 & 0.494 & -0.417 & -0.095 & -0.298 \\
\hline GSH-Px (IU mg-1 protein) & 0.397 & -0.307 & 0.602 & -0.430 & -0.291 \\
\hline CAT (IU mg mprotein) $^{-1}$ & -0.789 & 0.441 & -0.153 & -0.219 & -0.127 \\
\hline $\mathrm{AL}(\mathrm{cm})$ & 0.136 & 0.896 & -0.346 & -0.009 & -0.009 \\
\hline AW (g) & -0.219 & 0.903 & -0.262 & 0.079 & 0.117 \\
\hline \multicolumn{6}{|l|}{ Root } \\
\hline $\mathrm{GSH}$ (mg GSH $\mathrm{mg}^{-1}$ protein) & 0.926 & 0.074 & -0.222 & -0.060 & -0.242 \\
\hline TAA (mg AEE $\mathrm{mg}^{-1}$ protein) & 0.061 & -0.610 & -0.447 & 0.593 & -0.034 \\
\hline ABTS (mg AEE $\mathrm{mg}^{-1}$ protein) & 0.808 & 0.153 & -0.298 & 0.428 & -0.128 \\
\hline SOD (IU mg mprotein) $^{-1}$ & -0.803 & -0.493 & 0.129 & 0.169 & 0.088 \\
\hline GPx (IU mg-1 protein) & -0.738 & -0.002 & 0.464 & 0.385 & -0.122 \\
\hline PPx (IU mg-1 protein) & -0.887 & 0.015 & 0.295 & 0.291 & -0.079 \\
\hline LP (nmol MDA mg ${ }^{-1}$ protein) & 0.069 & -0.687 & -0.349 & -0.039 & -0.575 \\
\hline GSH-Px (IU mg-1 protein) & 0.838 & -0.009 & -0.151 & -0.137 & -0.455 \\
\hline CAT (IU mg mp $^{-1}$ protein) & -0.688 & -0.178 & 0.113 & 0.372 & -0.529 \\
\hline $\mathrm{AL}(\mathrm{cm})$ & -0.560 & 0.506 & -0.528 & 0.299 & 0.028 \\
\hline$A W(g)$ & -0.606 & -0.697 & 0.048 & 0.089 & 0.291 \\
\hline GE (\%) & -0.566 & 0.792 & 0.123627 & 0.051 & -0.092 \\
\hline $\mathrm{G}(\%)$ & -0.869 & -0.417 & -0.099842 & -0.089 & -0.168 \\
\hline
\end{tabular}

*Legend: GSH - Reduced glutathione; TAA - Total antioxidant activity; ABTS - Radical Cation Scavenging Activity; SOD - Superoxide dismutase; GPx - Guaiacol peroxidase; PPx - Pyrogallol peroxidase; LP - Lipid peroxidation; GSHPx - Glutathione peroxidase; CAT - Catalase; AL - Average length; AW - Average weight; GE - Germination energy; $\mathrm{G}-$ Germination.

In pepper shoots, significant positive correlation with germination was noticed with SOD, TAA, PPX, GPx, LP, CAT, and GSH. Additionally, significant positive correlations were also found between GE and AW with GPx, PPx, LP, and CAT (Table 3).

In pepper roots, significant positive correlations were found between germination and root weight with SOD, GPx, PPx, and CAT. Significant positive correlation was found between germination energy and GPx and PPx. On the contrary, significant negative correlations were found for GSH and GSH-Px with all root growth parameters - GE, G, root length and weight (Table 3). 
Table 3. Correlations of enzymes, antioxidant activity and growth parameters in pepper shoot (above 1) and root (below 1)

\begin{tabular}{|c|c|c|c|c|c|c|c|c|c|c|c|c|c|}
\hline & $\mathrm{L}$ & W & $G$ & GE & CAT & SOD & GSH-Px & GPx & PPx & LP & GSH & TAA & ABTS \\
\hline $\mathrm{L}$ & 1.000 & $0.883^{* *}$ & $-0.349^{*}$ & $0.562^{* *}$ & 0.315 & $-0.395^{\star}$ & -0.317 & 0.164 & 0.193 & $0.454^{\star \star}$ & $-0.444^{\star \star}$ & -0.084 & -0.094 \\
\hline W & 0.010 & 1.000 & -0.114 & $0.745^{* *}$ & $0.550^{\star *}$ & -0.158 & $-0.472^{\star *}$ & $0.353^{*}$ & $0.467^{* *}$ & $0.620^{* *}$ & $-0.364^{\star}$ & 0.006 & -0.113 \\
\hline G & 0.208 & $0.418^{*}$ & 1.000 & 0.266 & $0.395^{\star}$ & $0.666^{* *}$ & -0.156 & $0.455^{\star \star}$ & $0.489^{* *}$ & $0.435^{\star}$ & $0.356^{*}$ & $0.513^{\star *}$ & $0.421^{*}$ \\
\hline GE & $0.517^{\star *}$ & -0.208 & 0.267 & 1.000 & $0.656^{\star *}$ & 0.076 & $-0.351^{*}$ & $0.663^{\star \star}$ & $0.751^{* *}$ & $0.704^{\star *}$ & -0.299 & -0.067 & -0.205 \\
\hline CAT & 0.249 & $0.405^{\star}$ & $0.512^{\star \star}$ & 0.342 & 1.000 & $0.406^{*}$ & -0.305 & $0.763^{* *}$ & $0.820^{* *}$ & $0.737^{* *}$ & 0.121 & $0.409^{*}$ & 0.167 \\
\hline SOD & 0.119 & $0.798^{\star *}$ & $0.553^{\star *}$ & 0.005 & $0.610^{\star *}$ & 1.000 & -0.066 & $0.562^{\star *}$ & $0.474^{\star *}$ & 0.209 & 0.212 & $0.571^{* *}$ & $0.409^{*}$ \\
\hline GSH-Px & -0.331 & $-0.562^{\star \star}$ & $-0.518^{\star *}$ & $-0.428^{\star}$ & -0.342 & $-0.711^{\star *}$ & 1.000 & -0.060 & -0.230 & $-0.437^{\star}$ & 0.022 & $-0.393^{*}$ & -0.301 \\
\hline GPx & 0.207 & $0.466^{\star *}$ & $0.432^{*}$ & $0.505^{\star \star}$ & $0.781^{* *}$ & $0.639^{* *}$ & $-0.638^{* *}$ & 1.000 & $0.891^{* *}$ & $0.577^{\star *}$ & 0.002 & 0.320 & 0.146 \\
\hline PPx & 0.335 & $0.543^{* *}$ & $0.572^{\star *}$ & $0.558^{* *}$ & $0.783^{* *}$ & $0.723^{* *}$ & $-0.744^{\star \star}$ & $0.955^{\star *}$ & 1.000 & $0.643^{* *}$ & 0.018 & 0.275 & 0.082 \\
\hline LP & -0.132 & 0.179 & 0.141 & $-0.495^{\star *}$ & 0.167 & 0.077 & 0.286 & -0.155 & -0.137 & 1.000 & 0.117 & $0.374^{\star}$ & 0.284 \\
\hline GSH & -0.268 & $-0.517^{\star \star}$ & $-0.653^{\star *}$ & $-0.437^{\star}$ & $-0.514^{\star *}$ & $-0.714^{\star *}$ & $0.885^{\star *}$ & $-0.676^{\star *}$ & $-0.767^{\star *}$ & 0.181 & 1.000 & $0.541^{* *}$ & $0.595^{\star \star}$ \\
\hline TAA & 0.072 & $0.361^{*}$ & 0.134 & $-0.515^{\star *}$ & 0.194 & 0.311 & -0.011 & -0.059 & -0.059 & $0.538^{\star *}$ & 0.029 & 1.000 & $0.907^{\star *}$ \\
\hline ABTS & -0.069 & $-0.542^{\star \star}$ & $-0.571^{\star *}$ & -0.307 & $-0.397^{\star}$ & $-0.645^{\star *}$ & $0.694^{\star *}$ & $-0.534^{\star *}$ & $-0.647^{* *}$ & 0.098 & $0.786^{\star *}$ & $0.344^{*}$ & 1.000 \\
\hline
\end{tabular}


These results suggest that Trichoderma spp. could express two different strain-dependent modes of actions. One mode of action can be noticed in seedlings treated with TR-2, TR-3, TR-9, and TR-10, where positive correlation between PPx, SOD, and CAT activity and germination was registered, and ROS species acted as signal molecules which increased energy and germination. Another mode of action can be noticed in seedlings treated with Trichoderma isolates TR-5, TR-6, and TR-7 where ROS decreased and they did not act as signal molecules, which lowered germination energy and germination confirmed as well.

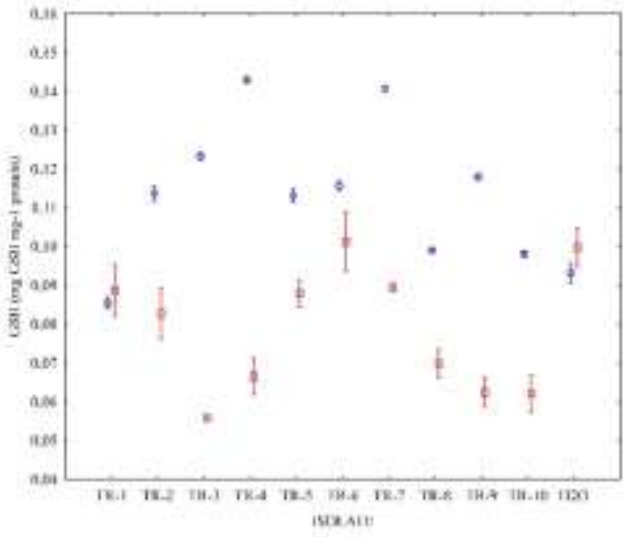

(a)

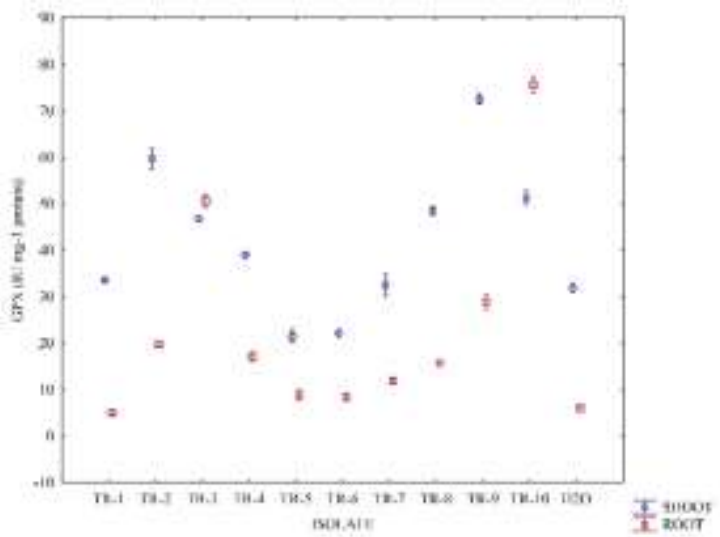

(c)

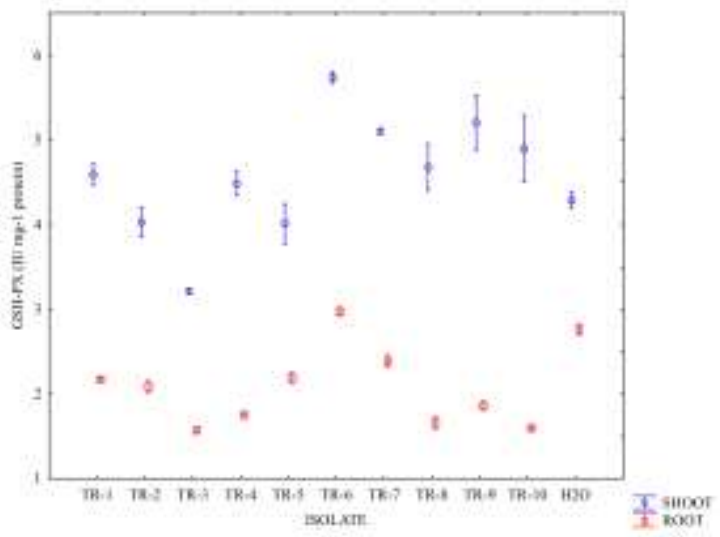

(e)

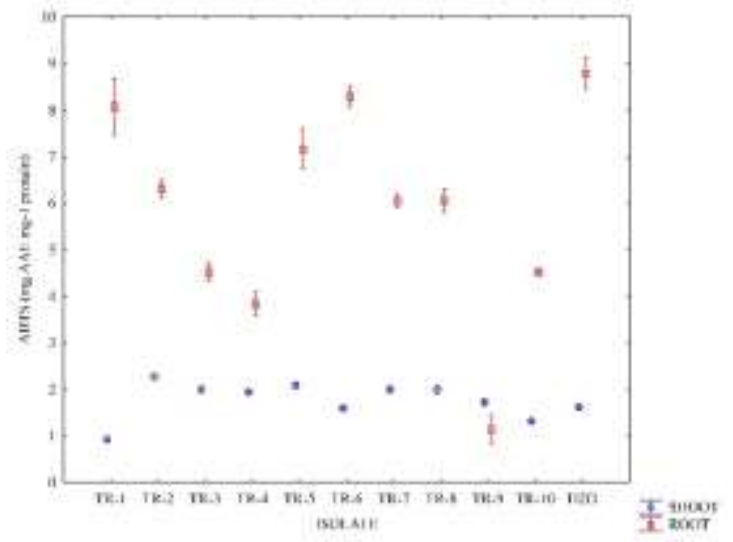

(b)

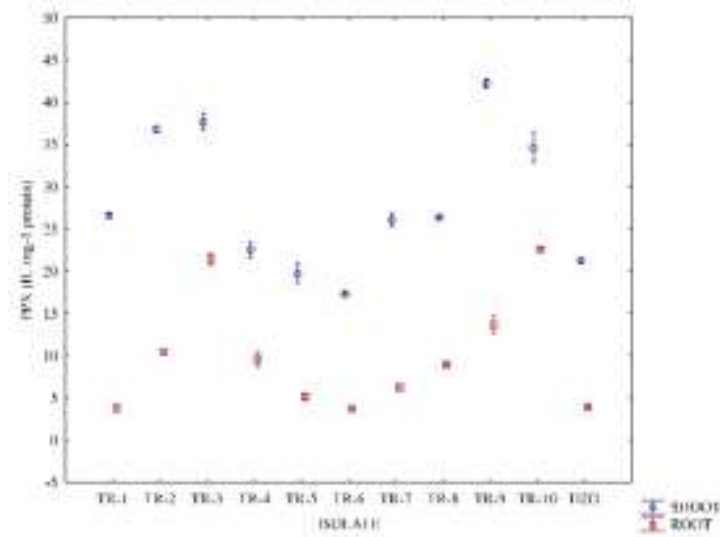

(d)

Figure 2. Trichoderma isolates effects on: A) reduced gluthatione (GSH), B) Radical Cation Scavenging Activity (ABTS), C) guaiacol peroxidase (GPx), D) pyrogallol peroxidase (PPx), E) gluthatione peroxidase (GSH-Px) in roots and shoots of pepper seedlings. Means of three independent experiments with three replicates; Bars represent standard errors. 


\section{DISCUSSION}

According to growth promoting analyses in this study, the most noticeable is the significant positive effect of Trichoderma isolates on the root weight of pepper seedlings. Besides root weight, some isolates positively affected the shoot weight as well. Root enhancement caused by T. harzianum treatment has been also reported for sweet pepper [28], and cucumber plants with $24 \%$ of roots dry weight and $45 \%$ of root length increase [29]. Significant increase of shoot length of pepper seedlings treated with T. harzianum was reported by Inbar and coathors [30], and by Joshi and coauthors [31] who registered both root and shoot length increase of chilli plants. In our study, root and shoot lengths were mainly unaffected by Trichoderma isolates - only one isolate out of ten tested had significant positive effect on these variables. This is in agreement with Tucci and coauthors [15], who noticed that $T$. atroviride and $T$. harzianum modified the root architecture of tomato in a differential way, and in most cases root length was unaffected, whereas lateral development was stimulated. Stimulated lateral development of pepper seedlings roots was the cause of the significant increase of root weight, although root length was unaffected in our study.

In current study, GE was positively affected by five isolates up to $40 \%$ increase in comparison with the control, while germination was significantly enhanced at the end only by two isolates, up to $22 \%$ of increase. Increase in seedling emergence up to 30\% was observed by Yedidia and coauthors [29] on cucumber seeds sown in Trichoderma-treated soil. Celar and Valic [32] studied the effects of different Trichoderma species on germination of onion, radish, spinach, carrot, tomato, cabbage, pea, red beet, chicory, lettuce, and maize seeds. In most cases, it only influenced the germination speed, but not the final number of germinated seeds, which was also the case in our study. Uniformity of pepper plants is very important in seedling production because those plants that germinate later will be significantly shorter and less competitive.

At the seedling physiology level, this study showed that Trichoderma could express two different straindependent modes of actions. Even though some authors $[33,34]$ demonstrated that Trichoderma species alleviate the effects of stress caused by any other biotic or abiotic factor, by deactivation of stress- and defence-related systems, our results indicate that some strains of Trichoderma could induce formation and accumulation of ROS. The increase of antioxidative enzymes activity (CAT, SOD, oxalate oxidase, peroxidase, etc.) suggests the involvement of ROS production in plants colonized with Trichoderma spp. $[35,36]$.

Recent information, suggests that ROS are not only stress signal molecules, but also have an important role in plant growth and development [37]. It could be supposed that during the colonization of pepper seed and seedling with some isolates, ROS species acted as triggering molecules which increased energy and germination. That is why a positive correlation between PPx, SOD, and CAT activity and germination was registered in plants treated with these isolates.

On the other hand, some of Trichoderma tested isolates had a completely different mode of action. Increased ROS formation led to the increase of gluthatione content in plant tissue and consequently higher GSH-Px activity. As a potent scavenger of free radicals, glutathione enhanced the antioxidant effect of the system itself which is proved by ABTS test. Shoresh and Harman [36] reported that other stress-related proteins that were up-regulated included glutathione-dependent enzymes. Plants detoxify some contaminants by conjugating them, or their metabolites, to glutathione. By increasing antioxidant activity in the system, the level of ROS decreased and they did not act as signal molecules. Because of that, lower germination and germination energy were observed in this study in plants treated with these isolates.

\section{CONCLUSIONS}

Perspective Trichoderma isolates induced formation and accumulation of ROS, which acted as signal molecules that increased germination energy and germination. Positive correlation was found between pyrogallol peroxidase, superoxide dismutase, catalase activity and germination in plants treated with these isolates. Nine out of ten Trichoderma isolates significantly increased root weight of pepper seedlings, while three out of ten positively affected shoot weight. Root and shoot lengths mainly remained unaffected.

After all, not all Trichoderma strains were effective for pepper growth promotion, but Trichoderma strains which can induce formation and accumulation of ROS, as an important factor in plant growth and development, are desirable for germination and growth improvement of pepper seeds.

Funding: This research was funded by Ministry of Education, Science and Technological Development of the Republic of Serbia, grants number TR31025 and TR31030. 


\section{REFERENCES}

1. FAOSTAT, 2018 [internet]. Food and Agriculture Organisation of the United Nations. [cited 2020 February 10]. Available from: http://www.fao.org/faostat/en/\#data/QC

2. Siri B. Vichitphan K, Kaewnaree P, Vichitphan S, Klanrit P. Improvement of quality, membrane integrity and antioxidant systems in sweet pepper (Capsicum annuum Linn.) seeds affected by osmopriming. Aust J Crop Sci. 2013; 7(13):2068-73.

3. Sadeghian SY, Yavari N. Effect of water-deficit stress on germination and early seedling growth in sugar beet. J Agron Crop Sci. 2004; 190(2):138-44.

4. Waskiewicz A, Beszterda M, Golinski P. Nonenzymatic Antioxidants in Plants. In: Parvaiz A, editor. Oxidative Damage to Plants. Elsevier; 2014. p. 201-34.

5. Bailly C. Active oxygen species and antioxidants in seed biology. Seed Sci Res. 2004; 14: 93-107.

6. Breusegem FV, Vranová E, Dat JF, Inzé D. The role of active oxygen species in plant signal transduction. Plant Sci. 2001; 161(3):405-14.

7. Mittler R, Vanderauwera S, Suzuki N, Miller G, Tognetti VB, Vandepoele K, Gollery M, Shulaev V, Van Breusegem F. ROS signalling: the new wave? Trends Plant Sci. 2011; 16 (6): 300-9.

8. Harman GE. Trichoderma - not just for biocontrol anymore. Phytoparasitica. 2011; 39:103-8.

9. FRAC, 2016 [internet]. Fungicide Resistance Action Committee. Resistance tables Benz. [cited 2017 Aug 17]. Available from: http://www.frac.info/docs/default-source/expert-fora/2004-06-11resistance_tables_benz.pdf.

10. Howel CR. Mechanisms employed by Trichoderma species in the biological control of plant diseases: the history and evolution of current concepts. Plant Dis. 2003; 87:4-10.

11. Vinale F, Sivasithamparam K, Ghisalberti E, Marra R, Woo SL, Lorito M. Trichoderma - plant - pathogen interactions. Soil Biol Bioch. 2008; 40:1-10.

12. Shoresh M, Harman GE, Mastouri F. Induced systemic resistance and plant responses to fungal biocontrol agents. Ann Rev Phytopath. 2010; 48:21-43.

13. Harman GE. Myths and dogmas of biocontrol. Changes in perceptions derived from research on Trichoderma harzianum T-22. Plant Dis. 2000; 84: 377-93.

14.Saba H, Vibhash D, Manisha M, Prashant KS, Farhan H, Tauseef A. Trichoderma - a promising plant growth stimulator and biocontrol agent. Mycosphere. 2012; 3(4):524-31.

15.Tucci M, Ruocco M, De Masi L, De Palma M, Lorito M. The beneficial effect of Trichoderma spp. on tomato is modulated by the plant genotype. Mol Plant Path. 2011; 12:341-54.

16. Asaduzzaman M, Alam MJ, Islam MM. Effect of Trichoderma on Seed Germination and Seedling Parameters of Chili. J Sci Found. 2010; 8(1-2):141-50.

17.Bal U, Altintas S. Application of the Antagonistic Fungus Trichoderma harzianum (TrichoFlow WP ${ }^{\mathrm{TM}}$ ) to Root Zone Increases Yield of Bell Peppers Grown in Soil. Biol Agric Hortic. 2012; 24(2):149-63.

18. Mukhtar I, Hannan A, Atiq M, Nawaz A. Impact of Trichoderma species on Seed Germination in Soybean. Pak J Phytopath. 2012; 24(2):159-62.

19. Maslienko LV. Substantiation and development of a microbiological method for controlling sunflower diseases [dissertation in Russian]: Krasnodar University, Russia; 2005. 71 p.

20.Mandal S, Mitra A, Mallick N. Biochemical characterization of oxidative burst during interaction between Solanum lycopersicum and Fusarium oxysporum f. sp. lycopersici. Physiol Mol Plant Pathol. 2008; 72:56-61.

21.Bradford MM. A rapid and sensitive method for the quantitation of microgram quantities of protein utilizing the principle of protein-dye binding. Anal Biochem. 1976; 72:248-54.

22.Sathya E., Bjorn M. Spectrophotometric Assays for Antioxidant Enzymes in Plants. In: Sunkar R, editor. Plant Stress Tolerance. Oklahoma USA: Humana Press; 2010. p. 273-81.

23.Morkunas I, Gmerek J. The possible involvement of peroxidase in defense of yellow lupine embryo axes against Fusarium oxysporum. J Plant Phys. 2007; 164:185-94.

24.Paglia DE, Valentine WN. Studies on the quantitative and qualitative characterization of erytrocyte glutathione peroxidase. J Lab Clin Med. 1967; 70:158-69.

25. Sedlak J, Lindsay H. Estimation of total protein bound and non-protein sulphyryl groups in tissue with Ellman's reagent. Anal Bioch. 1968; 25:192-205.

26. Berk S, Tepe B, Arslan S, Sarikurkcu C. Screening of the antioxidant, antimicrobial and DNA damage protection potentials of the aqueous extract of Asplenium ceterach DC. Afr J Biotechnol. 2011; 10 (44): 8902-08.

27. Re R, Pellegrini N, Proteggente A, Pannala A, Yang M, Rice-Evans C. Antioxidant activity applying an improved ABTS radical cation decolorization assay. Free Rad Biol Med. 1999; 26(9-10):1231-37.

28. Idowu OO, Oni AC, Salami AO. The interactive effects of three Trichoderma species and damping-off causative pathogen Oythium aphanidermatum on emergence indices, infection incidence and growth performance of sweet pepper. Int J Recent Sci Res. 2016; 7(4):10339-347.

29. Yedidia I, Srivastva AK, Kapulnik Y, Chet I. Effect of Trichoderma harzianum on microelement concentrations and increased growth of cucumber plants. Plant Soil. 2001; 235(2):235-42.

30. Inbar J, Abramsky M, Cohen D. Chet I. Plant growth enhancement and disease control by Trichoderma harzianum in vegetable seedlings grown under commercial conditions. Eur J Plant Pathol. 1994;100 (5):337-46.

31.Joshi BB, Bhatt RP, Bahukhandi D. Antagonistic and plant growth activity of Trichoderma isolates of Western Himalayas. J Environ Biol. 2010; 31(6):921-28. 
32.Celar F, Valic N, Effects of Trichoderma spp. and Gliocladium roseum culture filtrates on seed germination of vegetables and maize. J Plant Dis Protect. 2005; 112(4):343-50.

33. De Oliviera AB, Gomes-Filhob E, Eneas-Filhob J, Tarquinio Priscob J, Mendes Alencar LN. Seed priming effects on growth, lipid peroxidation, and activity of ROS scavenging enzymes in $\mathrm{NaCl}$-stressed sorghum seedlings from aged seeds. J Plant Interact. 2012; 2 (7): 151-59.

34.Chepsergon J, Mwamburi L, Kipkemboi KM. Mechanism of Drought Tolerance in Plants Using Trichoderma spp. Intl J Sci Res. 2014; 3(11):1592-95.

35.Brotman Y, Landau U, Cuadros-Inostroza A, Takayuki T., Fernie A., Chet I, et al. Trichoderma-Plant Root Colonization: Escaping Early Plant Defense Responses and Activation of the Antioxidant Machinery for Saline Stress Tolerance. PLOS Pathogens [internet]. 2013 [cited 2017 Avg. 19]; 9(3):e1003221. Available from: https://journals.plos.org/plospathogens/article?id=10.1371/journal.ppat.1003221

36. Shoresh M, Harman G. The Molecular Basis of Shoot Responses of Maize Seedlings to Trichoderma harzianum T22 Inoculation of the Root: A Proteomic Approach. Plant Phys. 2008; 147(4): 2147-63.

37.Karuppanapandian T, Moon JC, Kim C, Manoharan K, Kim W. Reactive oxygen species in plants: their generation, signal transduction, and scavenging mechanisms. Aust J Crop Sci. 2011; 5(6):709-25.

(C) 2020 by the authors. Submitted for possible open access publication under the terms and conditions of the Creative Commons Attribution (CC BY NC) license (https://creativecommons.org/licenses/by-nc/4.0/). 